\title{
AIRLINE PHILANTHROPY - INVESTMENT OR EXPENSE?
}

Deborah Ancell

University of Westminster

\begin{abstract}
Airlines are corporately socially and environmentally responsible (CSER). Unlike predecessor 'CSR', CSER acknowledges the importance of the environment. CSER-managed airlines obey the law, service customers safely, manage employees fairly, reward owners appropriately, pay suppliers promptly and mitigate environmental impacts. Unlike philanthropy (i.e. CSERplus), airlines' CSER-management is underpinned by economics - the optimal allocation of resources. External pressures push airlines to go beyond economically-viable, strategic investments to make philanthropic donations which are voluntary, discretionary contributions purportedly to further their interests. If the CSERplus philanthropic contributions are non-strategic they could increase costs without any benefit. Husted and Salazar (2006) determined three motivations for corporate entities to engage in strategic CSERplus (philanthropic) activities: either to (a) prevent unfavourable government intervention (b) create product differentiation to increase sales or (c) trigger cost reductions. Content and theme analysis of the top 10 airlines' CSER reports indicated that none of the three motivations applied to their philanthropic contributions. Philanthropy appeared to support the altruistic or egoistic interests of managers rather than the airlines. There were no success measures. In fact, philanthropic donations appeared to increase costs at a time when many airlines were reducing services and products to remain competitive. The conclusion is that airline philanthropy is an expense rather than an investment. This paper contributes to the paucity of current literature on philanthropic motivations and airline CSER management.
\end{abstract}

\section{KEYWORDS}

corporate social and environmental responsibility; CSER; CSR; philanthropy; costs

Dr Deborah Ancell is a Senior Lecturer at the University of Westminster, United Kingdom. Email: d.ancell@westminster.ac.uk, Tel.: +44 (0)20 35066637 


\section{INTRODUCTION}

According to the airline trade body, the International Air Transport Association (IATA), air transport "drives economic and social progress" (IATA, 2016) as it connects trade with "people, countries and cultures" while (among other benefits) paying taxes and wages, promoting social inclusion, delivering emergency aid and contributing philanthropy. Although airlines trumpet their philanthropy in their annual financial and corporate social responsibility (CSR) reports there is little examination as to the motives which drive such donations. This is significant because any contribution should be derived from profits which could have been diverted from provision of dividends for owners, rewards for employees, reduced customers' prices or improved suppliers' terms (among other possibilities). This paper (comprising a review of literature with context and thematic analysis) will attempt to determine whether the motivation for airlines' philanthropy is strategic investment or whether it is merely an expense. This dissection will explore the contributions of 10 airlines (and in some cases, their passengers) in one financial year (2015-16) to various charitable endeavours. One of the key findings was the identification of possible 'genteel extortion'. Another finding included the potential negative effects on competitiveness and the absence of identifiable, measurable and strategically justifiable outcomes for donations of all types (money, goods or services). This paper represents a contribution to the lack of literature on the theoretical dimension of airlines' philanthropic motivations. It also contributes to airlines' CSR management indicating the necessity for philanthropic measurement to ensure that such contributions are effectively and efficiently focussed for the benefit of the business and not the managers.

\subsection{Corporate Social Responsibility (CSR)}

Focusing on corporate responsibilities of all types leads to identifying the characteristics of well-managed organisations. These include competitive advantage derived from lower costs, reduced risks, strategic financial management and increased loyalty from employees, investors and customers (sources: many authors including Porter and Kramer, 2006; Brammer and Millington, 2008; Lynes and Andrachuk, 2008; Martinez and Bosque, 2008; Nikbin et al., 2016). In past decades, the all-encompassing term 'corporate social responsibility' (CSR) has become a mantra. It has two fundamental concepts: stakeholders and licensing.

\subsection{Stakeholders}

The concept of 'stakeholder' makes an entity responsible to more of society and any industry is now considered responsible for and to its multitude of stakeholders. This concept "allows each stakeholder - including the managers - to elevate pursuit of his own interests over both the ostensible organisational objective and the interests of other stakeholders" (Sternberg, 
2009: 7). Such elevation can be triggered by egoism (utility derived from one's own consumption) or altruism (utility derived from the consumption of others as well as one's own) (Husted and Salazar, 2006). Aside from altruism, an individual's contribution to charity has many motives including "guilt, sympathy, an ethic for duty, a taste for fairness, or a desire for recognition" (Andreoni, 1988: 57).

Stakeholders can be primary (essential to the organisation) or secondary (influencing or affecting the firm but not transacting with it) (Clarkson, 1995). Airlines' primary stakeholders include the owners, employees, customers, suppliers and regulatory bodies. Secondary include non-governmental organisations (NGOs) and other public interest groups such as communities affected by their operations. In a 'grey' area between the two are their competitors with which they sometimes have to transact. Airlines touch many groups and individuals in a 'principal-agency' relationship i.e. where the owners (as principals) appoint managers as their agents to act on their behalf. As agents, managers are encouraged to consider operational impacts on those parties with an interest in the airline i.e. the 'stakeholders' which the World Business Council for Sustainable Development (WBCSD) (a CEO-led global advocacy association for social and environmental concerns) describes as "society at large" (WBCSD, 1999: 3). However, the wider 'stakeholder doctrine' damages the principal-agency relationship (Ancell, 2017), weakens accountability, suffers from practical defects which undermine its justification and attracts "the promoters of worthy causes who (unrealistically) believe they would be the beneficiaries if organisational (and particularly business) assets were diverted from their owners" (Sternberg, 2009:7-8). Many of these 'promoters' target airlines to be contributors to their causes and persuade agent-managers to behave like principals (i.e. owners). They also decide what they believe will be in the public good however it is not clear how unelected private individuals decide what is in the interest of wider society (Friedman, 1982).

\subsection{Licensing}

Licensing is a means by which governments can protect consumers and in the CSR context, the implicit 'licence to operate' "is what organisations receive when they become accountable to society through the stakeholders" (Ancell, 2017: 32-33). This 'licence' is awarded by stakeholders including national, multi-national and supra-national governments (NMSGs), NGOs, customers and suppliers. It is retained by virtue of commercial organisations adhering to legislation and regulations. However, it can be argued that the implicit 'issue' of such a licence actually undermines free society because in free society, what is not prohibited by law is actually permissible (Sternberg, 2009). Such a 'licence' could even pose a threat to 
operations i.e. business must submit to society or it could be prevented from trading (another form of 'genteel extortion'). It could therefore be argued that any 'licence' (issued under the guise of CSR) is actually "inimical to liberty" (Sternberg, 2009: 8).

\section{ESTABLISHING CSR}

\subsection{Defining CSR}

CSR has multiple similar definitions from many recognisable sources. The European Commission (2002: 3) (an institution of the European Union (EU) which proposes legislation, implements decisions, upholds EU treaties and manages day-to-day EU business) decided that CSR was a "... concept whereby companies integrate social and environmental concerns in their business operations and in their interaction with their stakeholders on a voluntary basis" [emphasis added]. CSR is also perceived as a grouping of corporate activities aimed to "further some social good beyond the interests of the firm and that which is required by law'[emphasis added] (McWilliams and Siegel, 2001: 117) or as "a commitment to improve community well-being through discretionary business practices and contributions [emphasis added] of corporate resources" (Kotler and Lee, 2005). CSR's impacts are on the "triple bottom line" of "people, planet and profit" and reflect how a commercial entity "... acts voluntarily [emphasis added] to ensure the most beneficial outcomes for all its stakeholders ... [including]... the wider communities which businesses serve" (Coles et al., 2013: 71).

CSR is also an important element of the work programme of the United Nations (UN) through the UN Conference on Trade and Development (UNCTAD) "...which seeks to bring together key stakeholders that can promote responsible international investment practices and contribute to sustainable development around the world." (UNCTAD, 2013). Furthermore, "CSR is best conceptualised at the level of the individual business as means of delivering higher aspirations for, and collective action necessary to achieve, sustainable development" (Coles et al., 2013 citing Plume, 2001). Unfortunately, the idea of 'sustainable development' is often confused with CSR. 'Sustainable development' evolved from the 1992 UN Sustainable Development (UNSD) Conference in Rio de Janeiro which delivered a global plan, Agenda 21. The plan encompassed land, forests, population and worldwide human activities and required developed world commercial organisations to 'voluntarily' contribute to developing nations. This was endorsed by the WBCSD which defines CSR as "...the continuing commitment by business to behave ethically and contribute to [developing world] economic development while improving the quality of life of the workforce and their families as well as the local community and society at large" (WBCSD, 1999: 3). 
Such 'voluntary', ' discretionary' 'contributions' beyond that 'which is required by law' is not the generally recognised definition of CSR and yet this is how its definers appear to have intended. CSR requires contributions by managers to causes which might have neither direct relevance nor resonation with either the business or its owners. The managers are merely passing on their own conception of what is in the public interest. This 'contribution' which "... is not considered a duty or social responsibility of business... but something that is merely desirable or beyond what duty requires..." (Schwartz and Carroll, 2003: 505-506) was the ultimate purpose when various NMSGs and NGOs invented CSR. Such contributions are philanthropic. Many philanthropic projects ultimately provide public goods for which there is no market and where managers (having decided on their concept of desirable public goods) allow private enterprises to replace governments in provision. This undermines the efficiency of markets. It is governments' role to provide where there is no market for private enterprise to fulfil.

\subsection{Claimed benefits of CSR}

Corporately responsible behaviour benefits airlines; airlines' accidents are expensive. However, illustrating the muddled definitions which have characterised CSR are claims that the initiatives enhance a firm's competitive advantage "to the extent that they influence the decisions of the firm's stakeholders in its favour ... In other words, one or multiple stakeholders will prefer the firm over its competitors specifically because of the firm's engagement in such CSR initiatives..." (Carroll and Shabana, 2010: 98-99). However, if CSR comprises contributions which take the organisation beyond that which it is legally required to do, it is possible these actions could be misinterpreted as 'bribery' or even "genteel extortion" (Ancell, 2017: 31) particularly if employed to minimise the effects of an untoward event or to prevent disruption. Philanthropy should not be used as a tool to offset unfavourable corporate occurrences. Some writers claim that "funding CSR activity is a popular technique for building a strong CSR reputation" (Nikbin et al., 2016: 358) which is purported to allow a firm to charge higher prices. The philanthropy-based, price benefits of a "strong CSR reputation" are unclear. In the highly-competitive aviation marketplace, price is the customers' first consideration accompanied by expectations of matched, price-based quality (Wittman, 2014). Whether passengers would willingly pay more if they were aware of the airlines' 'voluntary', 'discretionary'CSR 'contributions'is unknown. However, because of competition, passengers who are unhappy with market-based price or quality usually have many choices. The market will rule. 


\section{REDEFINING CSR}

The "airline industry's adoption of CSR is still relatively slow" (Kuo et al., 2016: 184). This is understandable if CSR equates to "discretionary business practices", "contributions to economic development" or "voluntary" "discretionary" spending beyond that "which is required by law"which will not contribute to corporate profitability. Economically sustainable entities' social and environmental behaviours are underpinned by economics marked by allocative and productive efficiency. Therefore 'CSR' - now more accurately identified as 'philanthropy' - is insufficient to describe all the dimensions of corporate interaction that some writers intended. In order to differentiate CSR's responsible economic, social and environmental management from CSR as philanthropy, it is therefore more appropriate to redefine 'CSR' as 'corporate social and environmental responsibility' i.e. 'CSER' (Ancell, 2017: xi). CSER organisations ensure consistent, reliable and safe product quality, reward owners, pay suppliers promptly, strive for healthy employee relations and safe workplaces, recruit diverse workforces, exhibit strong financial stewardship, protect the environment, compete fairly and operate legally. These organisational characteristics are sustained by law and supported by regulations. Consequently, any philanthropic contribution would be voluntary, discretionary and not integral to CSER management practices. The airline industry is heavily regulated and as such must operate within laws applicable in all destinations. In response to pressures from many NGOs, developed world NMSGs produce an ever-increasing quantity of laws and regulations affecting the multiple CSR dimensions. This means there is less discretion for corporate organisations to act other than within the bounds of the law i.e. 'responsibly'. If an airline does not exercise regulatory compliance it will be fined and could ultimately fail because passengers and freight forwarders will lose confidence and avoid it. Again, the market will rule.

However, if an entity behaves responsibly in all CSER dimensions it will most likely exhibit strong financial performance which could allow it to indulge in 'voluntary', 'discretionary'CSR 'contributions'. This philanthropy is 'CSR/CSERplus'. In summary: two elements have emerged: CSER (management) and CSR/CSERplus (philanthropy). Introducing these clarified abbreviations makes a clear distinction between behaviours which keep airlines economically, socially and environmentally viable (i.e. CSER) - and those which under pressure from NMSGs and NGOs are voluntary, discretionary contributions beyond legal requirements (i.e. CSR/CSERplus). Definitions matter. 


\subsection{CSER and CSR/CSERplus}

NMSGs and NGOs do not recognise CSER-management as 'business as usual'. They push for corporate entities to deliver increased voluntary, discretionary contributions beyond legal requirements to society and the environment (i.e. CSR/CSERplus-philanthropy) which fulfil the definitions of earlier authors (WBCSD, 1999; McWilliams and Siegel, 2001; European Commission, 2002; Schwartz and Carroll, 2003; Kotler and Lee, 2005; UNCTAD, 2013; Coles et al., 2013) (Figure 1).

Figure 1: the CSER and CSR/CSERplus model

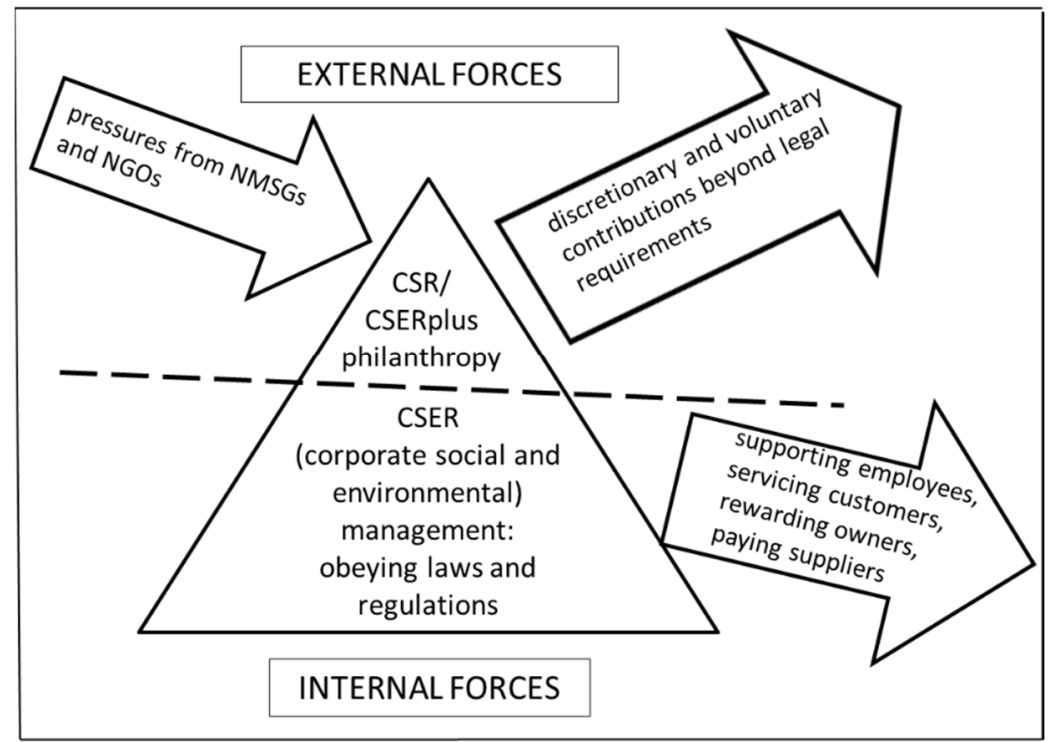

\subsection{Advocates' pressures}

With the increased awareness of world problems and the fact that business has from time to time included many bad actors (notably in financial institutions e.g. the investment industry) commercial entities (including airlines) have been asked to solve many of the world's social and environmental problems by donating owners' funds or employees' rewards.

The NMSGs and NGOs want airlines' voluntary, discretionary contributions beyond legal requirements to fund their social or environmental aims and yet any spending which does not contribute to profits cannot be sustainable in the long run (Vogel, 2005; Inoue and Lee, 2011). Without profits there would be no long term, sustainable, viable entity to act responsibly. Larger firms which are more profitable and which spend more on advertising, research and development are "expected to make donations at a higher rate" (Brammer and Millington, 2008: 1335). Where airline customers, employees or investors perceive little or no economic value from CSR activities, any such spending might even be counterproductive (Seo, Moon and Lee, 2015) and since "CSR activities are often costly while providing little or no direct benefit, the additional costs of CSR can serve business negatively" (ibid: 131). 
The UN, through the UN Framework Convention on Climate Change (UNFCCC), argues that the drive for economic success in the developed world has triggered anthropogenic-caused global warming (AGW) (UN Intergovernmental Panel on Climate Change (IPCC), 2013). AGW has merged social and environmental interests into a cause which was clearly espoused by the UNFCCC Executive Secretary who noted that "...the fight against climate change is a process..." and, in echoes of Agenda 21, would only be achieved by "...the necessary transformation of the world economy..." (UN Regional Information Centre (UNRIC), 2015). Furthermore the UN believes that it should be able to change the capitalist economic model to redistribute wealth and thereby create more equitable societies. This requires voluntary, discretionary contributions beyond legal requirements from developed nations to developing nations - monies which will be derived from purchasers of their goods and services (i.e. in the market) and taxpayers. To assist this goal many NMSGs have adopted the various UN climate change protocols with which the airline industry has had to comply by passing on environmental taxes to passengers. One such scheme is the EU's Environmental Trading Scheme which demonises and monetises carbon dioxide $\left(\mathrm{CO}_{2}\right)$ and other gases. It initially included aviation from 2012 (EU, 2016) and purportedly would have been competition-neutral. In addition, airlines offer passengers the opportunity to voluntarily offset and monetise their emissions. Passengers' donations are despatched to various charities often using an intermediate financial institution. Administration costs of these schemes is an airline cost.

The UN's stance is in contrast to the frequently-quoted writings of Friedman (2007) who believed that the social responsibility of business was to increase profits which would filter into the national economy. All wealth is created by business so it is to business that noncommercial organisations such as NMSGs or NGOs turn for resources. Redistribution of corporate earnings into charitable causes (i.e. CSR/CSERplus) is neither economically productive nor allocatively efficient. It can also undermine owners' wishes if chosen by managers without consultation (another breach of the principal-agency relationship). Alternative responses to these external pressures comprise reacting by resisting (invoking "the trade-off between socially responsible behaviour and profitability" (McWilliams and Siegel, 2000: 607)), defending (by doing what is required), accommodating (by being slightly progressive) or proactively lead the industry (as innovators) (Carroll, 1979). Any of these options could lead to a less than optimal allocation of airlines' resources when airlines are offering "relatively identical products and services in similar price ranges" (Lee, Seo and Sharma, 2013: 23). They are innovating continuously pushing through barriers to attain competitive advantage while lowering costs. 


\subsubsection{Profits vs costs}

The importance of profits cannot be underestimated in a market economy. However, profits are generally perceived to be of two types: 'good' profits (which are made without exploiting customers, employees or suppliers) and 'bad' profits (which come from exploitative behaviours) (Dowling, 2008). There is some argument that CSR/CSERplus donations could offset any 'bad' profits. However, as signs of 'good' profitability, airlines seek ethical awards (awarded by self-appointed 'ethical expert' NGOs) to illustrate their favourable CSR/CSERplus characteristics while cutting costs which can negatively impact on customers' perceptions. One such example is the full service carriers (FSCs) charging customers for selected items which were previously complimentary (e.g. meals) while continuing philanthropic programmes. This trade-off - complimentary passenger meals or philanthropy - is not transparent because the costs of both are not disclosed. FSCs are under pressure from low cost carriers (LCCS) to continue profitability in highly competitive conditions with the often conflicting goals of lowering costs and prices while improving services.

\subsubsection{Advocacy vs research}

Airlines are pressured to voluntarily provide philanthropic contributions. This is evidenced by researchers who surveyed airline passengers seeking confirmation that "this airline company tries to help the poor" (Iklhanizadeh and Karatepe, 2017: 14), "prioritises areas in CSR practices", "donates money to charitable organisations" and "encourages employees to engage in voluntary social events" (Kucukusta, Guillet and Chan, 2017: 460). Although such leading statements are more advocacy than research they do serve to reinforce CSR/CSERplus philanthropy while simultaneously providing misleading conclusions which can be used to sway NMSGs and NGOs. Although CSR/CSERplus can be expressed as an activity "in terms of purchasing or non-purchasing behaviour ... [or] ... expressed as opinions in surveys or other forms of market research" (Devinney et al., 2006: 32), self-defined, 'socially-responsible' consumers' actions do not always match their espoused behaviours i.e. "consumers are not willing to put their money where their mouths are..." (ibid: 32). Their "morals stop at the pocket book. People may say they care but they will always buy the cheaper brand" (ibid: 32). That being the case, many consumers might not be represented by the NMSGs and NGOs which pressure airlines to donate to their causes. However, there has to "be a clear [psychological] connection between social features and functional features" because "sociallyconscious consumers will not sacrifice functional features for socially acceptable ones" (ibid: 36) e.g. FSC's cutting costs by reducing passengers' legroom vs voluntary, discretionary contributions beyond legal requirements. 


\subsubsection{CSR/CSERplus motivation}

The CSR/CSERplus expectations of airlines has been fuelled by many NGOs and charities often purposefully formed to deal with both existing and new social and environmental challenges. However, such responsibilities displaced onto commercial entities are more correctly the domain of governments' spending of citizens' taxes in accordance with the will of their electorates (Friedman, 2007).

There are three motivations for corporate entities to engage in strategic CSR/CSERplus which could also increase the value of the firm (Husted and Salazar, 2006):

(a) preventing unfavourable government intervention (such as proposing an emissions tax)

(b) seeking an opportunity to differentiate products (to increase sales) or

(c) enabling cost reductions (to maintain competitiveness).

However, despite voluntary, discretionary contributions, airlines did not succeed in preventing environmental taxes (such as EU ETS) and furthermore, alignment with charities is not known to have increased seat or freight sales which could be the only economically beneficial effect if a "strong CSR reputation" (Nikbin et al., 2016: 358) is to be corporately rewarding.

Typically firms "...have a portfolio of [CSR/CSERplus] projects, some of which may be coerced [i.e. 'genteel extortion'], others altruistic, and still others strategic in nature" (Husted and Salazar, 2006: 87). The CSERplus costs are borne by owners (through lower dividends), employees (from reduced rewards), customers (by increased prices) or suppliers (by unfavourable terms) (Friedman, 2007; Ancell, 2017). The pursuit of CSR/CSERplus philanthropy has also been attributed to altruistic or egoistic managers pursuing their own interests instead of value for the business owners (Husted and Salazar, 2006; Friedman, 2007; Ancell, 2017) because such "... an opportunistic and self-serving manager may use ... CSR ... to increase his or her personal social status" (Fang, Huang and Huang, 2010: 120). This egoism (Husted and Salazar, 2006) is also another manifestation of the principal-agency problem.

\subsubsection{Advertising and cause-related marketing}

However, some "philanthropy can also be perceived as a form of sponsorship" (Ancell , 2017: 167). Many airlines broadcast their generosity because "...many of the benefits of being socially responsible are contingent upon awareness of firm behaviour among stakeholder groups..." (Brammer and Millington, 2008: 1330). One means of advertising is to invoke cause-related marketing (CRM) whereupon a charity (with expertise) and a company (with resources) could join forces to solve social or environmental problems. In theory this should 
create business value for the company which can then use it as a vehicle to increase sales with perhaps a percentage going to the aligned charity. Such support is commerciallymotivated, strategic philanthropy and is clearly perceived as a strength (Scholten, 2008) by the airlines which broadcast it in their CSER or CSR/CSERplus reports. While CRM might bring "financial benefits through increased revenues or reduced costs" (Brammer and Millington, 2008: 1330 ) it is estimated that $30-50 \%$ of US companies have no measures of return on such investment including "cost per reach" and "sales related to sponsorship spend" (Jacobs, Jain and Surana, 2014). "Advertising plays an important role in capturing the value of CSR actions" (McWilliams and Siegel, 2001: 1488). Furthermore, CRM's influence on consumers' choice "is found to depend on the perceived motivation underlying the company's CRM efforts as well as whether consumers must trade-off company sponsorship of causes for lower performance or higher price" (Barone, Miyazaki and Taylor, 2000: 248) e.g. airlines pursuing philanthropy while simultaneously reducing much-prized passenger legroom by installing an extra row of seats to increase corporate revenue.

\subsubsection{CSER and financial performance}

Despite the foregoing, price is the greatest determinant of passenger choice (IATA, 2015) so airlines (particularly international carriers) must be extremely cost-conscious in order to remain competitive. There is no 'one size fits all' model for CSER-managed airlines therefore decisions ranging from investments through to philanthropy will vary with each carrier. The CSR literature appears focussed on whether those firms actively pursuing the CSR ideals behave ethically and create social value (McWilliams and Siegel, 2001; Fang et al., 2010; Carroll and Shabana, 2010). Unfortunately, claims of CSR links to successful corporate financial performance are not consistent (McWilliams and Siegel, 2000). From these uncertainties, a new financial industry has evolved: socially responsible investment. Socially responsible investors (SRIs) are the self-appointed arbiters of ethical social and environmental concerns and yet "socially responsible investment funds perform no better than non-socially screened funds and many relatively responsible companies have not been financially successful" (Vogel, 2005: 19). SRIs believe that there is a strong correlation between social and financial performance and that CSR/CSERplus is "simply the right thing to do" (Carroll and Shabana, 2010: 92).

Some authors write of a relationship that is insignificantly positive (Mwangi and Jerotich, 2013), positively correlated (Lee, 2008) or neutral (McWilliams and Siegel, 2001) while others claim that the CSR/CSERplus dimensions "had a differential effect on both short term and future profitability" (Inoue and Lee, 2011: 790). Scholten (2008) in the attempt to decide 
"causality between corporate financial performance and corporate social performance" noted that "it appears that financial performance (both risk and return) in general terms precedes social performance (both strengths and concerns) much more often than the other way around." (ibid: 52). In other words, organisations must make profits before they can make voluntary, discretionary contributions beyond those which are legally required.

Costs of CSER-managed companies are included in corporate annual accounts. However, the costs of CSR/CSERplus activities are often difficult to monetise without inside knowledge because their measures are not consistent (including "staff volunteering hours", "donations in kind", "complimentary or reduced price seats or freight"; plus unidentified administrative costs for passenger "cash collections" and "student work experience"). Furthermore, the costs of administering the philanthropic disbursements are obscured in the CSER operating costs rather than the clarified CSR/CSERplus philanthropic totals.

\subsubsection{CSERplus costs and benefits}

Measuring the CSERplus programmes' costs and benefits and private and social returns can be difficult particularly because public social goods are not traded in markets (McWilliams and Siegel, 2011). Furthermore, "Firms in environmentally damaging industries such as mining, and those in consumer oriented sectors such as retailing, give significantly more heavily to charity than other firms, while firms in newer, cleaner industries such as the IT and electronic equipment sectors give significantly less heavily ..." (Brammer and Millington, 2008: 1335). It could be argued that airlines fit into the former category.

\subsubsection{Reputation}

Airlines compete on their customer service reflected in their reputations. They do not compete on their voluntary, discretionary contributions. Annual awards such as those conferred by world airline ranking Top 100 Airlines (Skytrax, 2016) are much sought after by carriers as these are based on the successful fulfilment of customers' requirements on ground and on board (Table 1). It would appear that philanthropy is not included in the criteria by which passengers judge an airline (Table 1 ).

\subsubsection{Reporting}

NGOs, NMSGs and advocates of CSR encourage (and in some jurisdictions (e.g. EU) mandate) corporations to annually report their social and environmental successes as an adjunct to their financial statements. The annual repackaging of on-going operational highlights results in a CSER-management report of successful decision-making and how economic stewardship of 
resources has contributed to the viability of the airline (Ancell, 2017). CSR/CSERplus reports are a form of advertising with a cascading readership: government and owners ( $1^{\text {st }}$ equal), customers ( $\left.3^{\text {rd }}\right)$ and employees ( $4^{\text {th }}$ equal with managers) (Kuo et al., 2016: 190). NGOs ranked $9^{\text {th }}$ (ibid). However, commercially successful entities put their employees first because customers are influenced by employees' satisfaction which ultimately influences profits (Yee, Yeung and Cheng, 2008).

Table 1: Skytrax airline ranking criteria (Skytrax, 2016)

\begin{tabular}{|l|l|l|}
\hline Ground/airport & Onboard: product & Onboard: staff service \\
\hline Airline web site & Cabin seat comfort & Assistance during boarding \\
Online booking & Cabin cleanliness & Friendliness and hospitality \\
Online check-in & Toilet cleanliness & Service \\
Airport ticket counters & Cabin lighting / ambience & attentiveness/efficiency \\
Waiting times at check-in & Cabin temperatures & Consistency of service \\
Quality of check-in service & Cabin comfort amenities & Staff language skills \\
Self check-in & Reading materials & Meal service efficiency \\
Boarding procedures & Airline magazine & Cabin presence thru flight \\
Pre-boarding procedures & Inflight entertainment & PA announcements \\
Friendliness of ground staff & Audio / movie programming & Assisting families \\
Efficiency of ground staff & AVOD options & Problem solving skills \\
Airline lounge product & Cabin WiFi and connectivity & Staff attitudes \\
facilities & Quality of meals & Staff grooming \\
Airline lounge staff service & Quantity of food & \\
efficiency lounge & Meal choices & \\
Airline staff & Selection of drinks / pay bar bar & \\
Hospitality & & \\
Transfer services & & \\
Arrival services & \\
Baggage delivery & & \\
\hline
\end{tabular}

Claims are that airlines publish CSR/CSERplus reports for reasons including burnishing reputation, government transparency, brand value, and employee and stakeholder communication (Kuo et al., 2016). There are however, barriers to reporting including timeconsuming preparation, confrontation of adverse sensitive information and data and potential to undermine corporate confidentiality (Kuo et al., 2016). Despite this firms are urged to be transparent in their reportage so that CSR/CSERplus stakeholders can determine the nonfinancial strengths and weaknesses of the firm. Such disclosures can also assist competitors. Other barriers to full disclosure include cost, doubting the potential advantages, lack of competitor equivalent disclosure or customers' concerns, possibility that it might damage the company's reputation or attract unwanted attention to topics which might need improvement with all the financial and legal complications that such disclosure could involve (Kuo et al., 2016). 
Despite the foregoing, "Most scholars note CSR reporting's benefits as a competitive advantage" (Kuo et al., 2016: 184). There is, however, a difference between the worlds of 'scholarship' and commerce and it is often difficult to differentiate research from advocacy. The number of customers who read annual CSR/CSERplus reports is not known and yet it is with them that "competitive advantage" would be most valuable. CSR/CSERplus reports are often colourful, comprehensive and complex delving deeply into an organisation's CSER management and CSR/CSERplus philanthropy. Given the detail they would be an expensive output and potentially a productively and allocatively inefficient use of corporate resources.

\subsubsection{Measures of strengths and concern}

Currently, a "lack of consistency due to different measurement frameworks and reporting structures" (Cowper-Smith and de Grosbois, 2011: 60) makes inter-firm achievements incomparable. SRIs urge transparency and full disclosure and call for these reports to be comparable by standardising formats such as those advocated by NGOs e.g. the Global Reporting Initiative, International Integrated Reporting Council or the US Sustainability Accounting Standards Board. However, there is no single best method of categorising and assessing airlines' responses to SRI's views on CSR/CSERplus strengths and concerns except perhaps obtaining memberships of CSR indices (such as FTSE4Good, Hang Seng Corporate Sustainability Index or Dow Jones Sustainability Index). Criteria are variable depending on who is making the judgement (Table 2) about what is in the interests of society (Friedman, 1982).

SRIs show concern for the industries which they determine are socially or environmentally unethical (e.g. military contracting or nuclear power (Kinder, Lydenburg, Domini (KLD) n.d.). This filtering tends towards bias. (Some SRIs even ignore 'economic prosperity' as a measure of strength or concern.) Lee et al., (2013: 20) categorised airline CSR data into operationrelated (OR) and non-operation-related (non-OR) i.e. two levels of CSR. OR-CSR categories include "improvements to product quality, employee relationships or treatment, and corporate governance" (ibid: 21). These are, in fact, the basic behaviours of any well-managed, CSER business. Non-OR items are "those CSR activities that firms ought to engage as ethical or responsible, societal citizens, despite a lack of direct implications for a firm's operations.... human rights, develop community relationships, support environmental issues and encourage diversity" (ibid: 21). This is actually CSR/CSERplus. These voluntary (non-OR) behaviours actually include some which could be OR especially if they require fulfilment under regulations (e.g. some environmental issues). Other authors have proposed different criteria. Schwartz and Carroll (2003) proposed a Venn-diagram with a three-dimensional framework: economic, 
legal and ethical rings which absorbed the philanthropic activities at the triple intersection. Becchetti and Ciciretti (2006) detailed the non-financial criteria which a commercial data provider could use to monitor the CSR performance of various US company stocks. Their categories covered strengths and concerns in the following: community, corporate governance, diversity, employee relations, environment, human rights and products. CowperSmith and de Grosbois (2011) included economic prosperity as well as social concerns. Inoue and Lee (2011) used five measures based on the KLD categories to determine how each would affect financial performance for tourism industries. The philanthropic areas included charitable and innovative giving, support for education, housing and volunteer programmes (in company time) and benefitting economically disadvantaged consumers. For CSERmanaged airlines (operating within regulations) measures of success include social (zero accidents), environmental (no fines for breaches) and economic (profitable).

Table 2: variable criteria of CSER and CSR/CSERplus strengths and concerns

\begin{tabular}{|c|c|c|c|c|c|c|}
\hline Measure & $\begin{array}{c}\text { KLD } \\
(1990)\end{array}$ & $\begin{array}{l}\text { Lee et al., } \\
\text { (2013) }\end{array}$ & $\begin{array}{l}\text { Schwart } \\
\text { z and } \\
\text { Carroll } \\
(2003)\end{array}$ & $\begin{array}{l}\text { Becchetti } \\
\text { and } \\
\text { Ciciretti } \\
(2009)\end{array}$ & $\begin{array}{l}\text { Cowper- } \\
\text { Smith and } \\
\text { de } \\
\text { Grosbois } \\
(2011)\end{array}$ & $\begin{array}{c}\text { Inoue } \\
\text { and Lee } \\
(2011)\end{array}$ \\
\hline economic prosperity & & & $x$ & & $\mathrm{x}$ & \\
\hline employee relations & $x$ & $x(\mathrm{OR})$ & & $x$ & $x$ & $x$ \\
\hline product quality (including safety) & $\mathrm{x}$ & $\mathrm{x}(\mathrm{OR})$ & & $\mathrm{x}$ & & $\mathrm{x}$ \\
\hline community relations & $\mathrm{x}$ & $\mathrm{x}(\mathrm{NON}-\mathrm{OR})$ & & $\mathrm{x}$ & $x$ & $\mathrm{x}$ \\
\hline environmental issues & $x$ & $\mathrm{x}(\mathrm{NON}-\mathrm{OR})$ & & $x$ & $x$ & $x$ \\
\hline diversity issues & $x$ & $x(\mathrm{NON}-\mathrm{OR})$ & & $\mathrm{x}$ & $x$ & $\mathrm{x}$ \\
\hline corporate governance & & $x(\mathrm{OR})$ & & $\mathrm{x}$ & & \\
\hline human rights & & $x(\mathrm{NON}-\mathrm{OR})$ & & $\mathrm{x}$ & & \\
\hline nuclear power & $\mathrm{x}$ & & & & & \\
\hline excessive executive compensation & $\mathrm{x}$ & & & & & \\
\hline quality programmes & $x$ & & & & & \\
\hline military contracting & $x$ & & & & & \\
\hline legal/economic/pure/ ethical & & & $x$ & & & \\
\hline ethical/economic/legal/pure & & & $\mathrm{x}$ & & & \\
\hline
\end{tabular}

\section{METHODOLOGY}

This research was not to assess the worthiness of airlines' CSERplus programmes but simply to determine whether there was an expressed motivation to satisfy any of the three Husted and Salazar (2006) categories. Airlines differ greatly in the quantity of documents, data and information provided. Determining the value and purpose of airlines' voluntary, discretionary contributions began with a literature search of the annual sustainability/CSR/CSERplus reports of top 10 airlines (Skytrax, 2016). Content analysis ("the accepted method of investigating texts" (Joffe and Yardley, 2004: 56)) was extended to thematic analysis in the search for specific patterns in the data of interest. Thematic analysis offers "an accessible and theoretically flexible approach to analysing qualitative data" (Braun and Clarke, 2006: 77). 
This involved "... establishing categories and then counting the number of instances in which they are used in a text..." (ibid). Codes 1 to 3 were allocated to each of Husted and Salazar's (2006) motivations (Table 3) to be treated as 'themes'. The code " 0 " was allocated if none of the motivations was discernible. The conclusions would be drawn from the raw information itself (inductive coding) (ibid).

Table 3: codes for Husted and Salazar's motivations

\begin{tabular}{|l|l|}
\hline Husted's and Salazar's motivations & Code \\
\hline no mention of any motivation & 0 \\
\hline prevent government intervention & 1 \\
\hline product differentiation to increase sales & 2 \\
\hline cost reductions & 3 \\
\hline
\end{tabular}

When assessing methodological quality it is appropriate to consider the clarity of the research question, whether the method proposed was the most appropriate and if the sample strategy would provide generalisable or transferable conclusions. Thematic content analysis fulfilled these requirements.

The airlines chosen were the top 10 from a population of 100 airlines surveyed by Skytrax World's Top 100 Airlines - 2016 (Skytrax, 2016) (Table 4).

Table 4: Reports for Skytrax top 10 airlines 2016

\begin{tabular}{|c|c|c|c|c|}
\hline $\begin{array}{l}\text { Skytrax } \\
\text { ranking }\end{array}$ & Airline & $\begin{array}{l}\text { Separate } \\
\text { sustainability/CSR/CSERplus } \\
\text { report and its title }\end{array}$ & $\begin{array}{l}\text { CSR/CSERplus } \\
\text { report incorporated } \\
\text { incol Annual } \\
\text { into } \\
\text { Report and } \\
\text { accounts }\end{array}$ & $\begin{array}{l}\text { Number } \\
\text { of } \\
\text { pages }\end{array}$ \\
\hline 1 & Emirates & -- & $\mathrm{x}$ & 179 \\
\hline 2 & $\begin{array}{l}\text { Qatar } \\
\text { Airways }\end{array}$ & x (Sustainability Report) & -- & 68 \\
\hline 3 & $\begin{array}{l}\text { Singapore } \\
\text { Airlines }\end{array}$ & x (Sustainability Report) & -- & 46 \\
\hline 4 & $\begin{array}{l}\text { Cathay } \\
\text { Pacific }\end{array}$ & $\begin{array}{l}\text { X (Sustainable Development } \\
\text { Report) }\end{array}$ & -- & 93 \\
\hline 5 & ANA & & $\mathrm{x}$ & 150 \\
\hline 6 & Etihad & $\mathrm{x}$ & -- & 28 \\
\hline 7 & $\begin{array}{l}\text { Turkish } \\
\text { Airlines } \\
\end{array}$ & x (Sustainability Report) & -- & 84 \\
\hline 8 & EVA Air & x (CSR report) & -- & 125 \\
\hline 9 & Qantas & x (Annual Review) & -- & 43 \\
\hline 10 & Lufthansa & x (Sustainability Report) & -- & 124 \\
\hline
\end{tabular}


Skytrax Awards recognise the quality and delivery consistency of products and services as voted for by international airline customers using CSER market-based, performance criteria (Table 1). The criteria omit any mention of airlines' CSR/CSERplus philanthropic programmes presumably because they are not considered important for customers whose choice is primarily price-determined (IATA, 2015). CSR/CSERplus comprise a minor part of any product's relevant attributes (McWilliams and Siegel, 2011). These airlines all produced CSER management and sustainability/CSR/CSERplus reports. However some airlines included those reports within the annual financial statements (e.g. Emirates, ANA) while others produced separate CSR/CSERplus reports (e.g. Qatar, Singapore). The examination of these airlines' CSR/CSERplus contributions excluded programmes which supported good business practice (e.g. by following the law or working to productively and allocatively efficient practices) therefore, by elimination, the research analysed a cross section of CSR/CSERplus programmes which were voluntary, discretionary contributions beyond those which are required by law. These programmes were assessed for their purpose according to the Husted and Salazar (2006) criteria (Table 5). 
TABLE 5: SUMMARY OF FINDINGS

\begin{tabular}{|c|c|c|c|c|}
\hline $\begin{array}{l}\text { SKY- } \\
\text { TRAX } \\
\text { RANK } \\
\text {-ING }\end{array}$ & $\begin{array}{l}\text { AIRLINE AND } \text { THEIR } \text { CSR/CSERplus } \\
\text { CONTRIBUTIONS i.e. PHILANTHROPY INCLUDE: } \\
\text { (NB: * denotes donated by passengers) }\end{array}$ & $\begin{array}{l}\text { COST OF CSR/CSERplus } \\
\text { PROGRAMME } \\
\text { (NB: 'not found' indicates the } \\
\text { monetised amounts were not } \\
\text { available in the report consulted) }\end{array}$ & $\begin{array}{l}\text { OPERATING } \\
\text { PROFIT/ } \\
\text { (LOSS) } \\
2015-16\end{array}$ & $\begin{array}{l}\text { PURPOSE } \\
\text { - no discernible strategic } \\
\text { motivation =0 } \\
\text { - prevent government } \\
\text { intervention =1 } \\
\text { - product differentiation } \\
=2 \\
\text { - cost } \\
=3\end{array}$ \\
\hline 1 & $\begin{array}{l}\text { Emirates: } \\
\text { - multiple education projects (Africa and Asia) } \\
\text { - anti-poaching rhino orphanage }\end{array}$ & AED2 million shared (matched fund) & AEDm 9,391 & $\begin{array}{l}0 \\
0\end{array}$ \\
\hline 2 & $\begin{array}{l}\text { Qatar Airways: } \\
\text { - wildlife and animal welfare }\end{array}$ & not found & QARm 3,048 & 0 \\
\hline 3 & $\begin{array}{l}\text { Singapore Airlines: } \\
\text { - community engagement } \\
\circ \text { multiple Singapore community projects } \\
\circ \text { rainforest } \\
\circ \text { children's causes and arts } \\
\circ \text { national programmes in many destinations } \\
\circ \text { humanitarian relief (particularly Nepal) } \\
\circ \text { medical charities } \\
\circ \text { staff volunteering } \\
\circ \text { staff support (e.g. music, sport, nutrition, education) } \\
\circ \text { charity flight } \\
\circ \text { USA charity support }\end{array}$ & $\begin{array}{l}\$ 5 \mathrm{~m} \text { Singapore to JY Pillay Global-Asia } \\
\text { Programme } \\
\text { not found } \\
\text { not found } \\
\text { not found } \\
\text { not found } \\
\text { not found } \\
\text { not found } \\
\text { not found } \\
\text { not found } \\
\text { business class tickets } \$ \text { US } 16,000\end{array}$ & $\$ \mathrm{~m} 681.2$ & $\begin{array}{l}0 \\
0 \\
0 \\
0 \\
0 \\
0 \\
0 \\
0 \\
0 \\
0\end{array}$ \\
\hline 4 & $\begin{array}{l}\text { Cathay Pacific (and Dragonair): } \\
\text { - food donation } \\
\text { - English on air (metrics available) } \\
\text { - staff volunteering } \\
\text { - charity sweaters *(passenger donated) }\end{array}$ & $\begin{array}{l}\$ H K 22 m \\
\text { not found } \\
\text { not found } \\
1300 \text { hours } \\
1 \text { million miles }\end{array}$ & \$USm 854 & $\begin{array}{l}0 \\
0 \\
0 \\
0\end{array}$ \\
\hline
\end{tabular}




\begin{tabular}{|c|c|c|c|c|}
\hline & $\begin{array}{l}\text { - wheelchair bank } \\
\text { - conservation* } \\
\text { - disadvantaged children* }\end{array}$ & $\begin{array}{l}\text { \$HK12m (cumulative since 1999) } \\
\text { \$HK9.5m } \\
\text { \$HK11.3 }\end{array}$ & & $\begin{array}{l}0 \\
0 \\
0\end{array}$ \\
\hline 5 & $\begin{array}{l}\text { ANA: } \\
\text { - UNESCO programmes in education, science and culture } \\
\text { including replacing thatched roofs } \\
\text { - hearty baths provided by employee volunteers } \\
\text { - free flights for rescuers for Japanese earthquake } \\
\text { - support for UN's Sustainable Development Goals } \\
\text { - biodiversity preservation } \\
\text { - blind football and other para sports } \\
\text { - tourism initiatives }\end{array}$ & $\begin{array}{l}\text { not found } \\
\text { not found } \\
\text { not found } \\
\text { not found } \\
\text { not found } \\
2000 \text { volunteers (hours unspecified) } \\
\text { not found } \\
\text { not found }\end{array}$ & $¥ 78.1$ bn & $\begin{array}{l}0 \\
0 \\
0 \\
0 \\
0 \\
0 \\
0 \\
0\end{array}$ \\
\hline 6 & $\begin{array}{l}\text { Etihad: } \\
\text { - } \quad \text { staff volunteering } \\
\text { - } \text { passenger donations* (Nepal Earthquake relief) } \\
\text { - } \text { charitable ticketing } \\
\text { - } \text { creatiple education projects (Africa and Asia) } \\
\text { - } \text { international leadership programme } \\
\text { - } \quad \text { surgical support and earthquake repairs for Nepal } \\
\text { - } \text { staff volunteering } \\
\text { - } \text { charitable passenger support } \\
\text { - } \text { carpets from uniforms } \\
\text { - composting }\end{array}$ & $\begin{array}{l}\text { not found } \\
21 \text { million miles (since 2014); } 30 \text { million } \\
\text { for Nepal } \\
300 \text { tickets for } 2014 \\
\text { not found } \\
\text { not found } \\
\text { not found } \\
\text { not found } \\
\text { not found } \\
\text { converting loyalty miles to cash } \\
\text { not found } \\
\text { not found } \\
\text { not found }\end{array}$ & $\begin{array}{lr}\text { US\$ } & 103 \\
\text { million } & (2015)\end{array}$ & $\begin{array}{l}0 \\
0 \\
0 \\
0 \\
0 \\
0 \\
0 \\
0 \\
0 \\
0 \\
0 \\
0 \\
0\end{array}$ \\
\hline 7 & $\begin{array}{l}\text { Turkish Airlines: } \\
\text { - Turkish Red Crescent } \\
\text { - solar power in Africa } \\
\text { - assorted African projects } \\
\text { - tents for Nepal earthquake } \\
\text { - tree planting }\end{array}$ & $\begin{array}{l}\text { not found } \\
10 \text { projects } \\
100 \text { projects } \\
1000 \text { tents } \\
500,000 \text { trees }\end{array}$ & $\begin{array}{l}\text { \$USm 1,069 } \\
(2015)\end{array}$ & $\begin{array}{l}0 \\
0 \\
0 \\
0 \\
0\end{array}$ \\
\hline
\end{tabular}




\begin{tabular}{|c|c|c|c|c|}
\hline 8 & $\begin{array}{l}\text { EVA Air: } \\
\text { - charitable activities } \\
\text { - athletic sponsorships } \\
\text { - local communities } \\
\text { - education (staff volunteering) } \\
\text { - arts and culture } \\
\text { - emergency aid } \\
\text { - medical subsidy } \\
\text { - disaster relief } \\
\text { - funeral/burial financial assistance }\end{array}$ & $\begin{array}{l}1.32 \% \text { of net income }=\$ 85 \mathrm{~m} \\
(\text { donation amount } \mathbf{N T} \mathbf{\$ 6 2 . 4 m}) \text { ) } \\
\$ 62.4 \mathrm{~m} \\
\$ 13.2 \mathrm{~m} \\
\$ 7 \mathrm{~m} \\
\$ 1.9 \mathrm{~m}=717 \text { hours } \\
12 \text { free tickets }+84 \text { special fares } \\
\text { not specified } \\
\text { not specified } \\
\text { not specified } \\
\text { not specified }\end{array}$ & $\begin{array}{l}\text { NT\$6.44 bn } \\
\text { (New Taiwan } \\
\$ \text { ) }\end{array}$ & $\begin{array}{l}0 \\
0 \\
0 \\
0 \\
0 \\
0 \\
0 \\
0 \\
0\end{array}$ \\
\hline 9 & $\begin{array}{l}\text { Qantas (Australia): } \\
\text { - community investment } \\
\text { - proportion of Aboriginal and Torres Strait Islander } \\
\text { investment } \\
\text { - UNICEF donations * } \\
\text { - World Vision* }\end{array}$ & $\begin{array}{l}>\$ A U 3.3 \mathrm{~m} \\
\$ A U 22.5 \mathrm{~m} \\
\$ A U 1.4 \mathrm{~m} \\
\$ A U 1.6 \mathrm{~m}\end{array}$ & \$AU 1.53bn & $\begin{array}{l}0 \\
0 \\
0 \\
0\end{array}$ \\
\hline 10 & $\begin{array}{l}\text { Lufthansa: } \\
\text { - humanitarian, refugee aid } \\
\text { - orchestra support } \\
\text { - football } \\
\text { - air crash bereavement endowment } \\
\text { - protection of logo-inspired crane } \\
\text { - staff volunteering } \\
\text { - on board collections* }\end{array}$ & $\begin{array}{l}€ 1 \mathrm{~m} \\
\text { not found } \\
\text { not found } \\
€ 15 \text { million } \\
\text { not found } \\
\text { not found } \\
€ 363,000\end{array}$ & $€ 1,776 \mathrm{~m}$ & $\begin{array}{l}0 \\
0 \\
0 \\
0 \\
0 \\
0 \\
0\end{array}$ \\
\hline
\end{tabular}




\section{FINDINGS AND DISCUSSION}

\subsection{Reporting}

The reports examined (Table 4) had many of the strengths and concerns identified by the SRIs (Table 2). The exceptions were 'military contracting', 'nuclear power' and 'excessive executive compensation'. The reports varied from highly detailed including monetised values of the direct contributions through to those which conveyed the minimum of information. Report titles were inconsistent: "corporate social responsibility", "sustainability" with one even titled "sustainable development" which did not fit with the definition from UNSD's Agenda 21. Many reports were glossy, colourful and extremely comprehensive with some containing as many as 179 pictorially- and photographically-illustrated pages (Emirates) through to a scant 28 (Etihad).

\subsection{Profits and contributions}

The top 10 airlines were profitable for the 2015-16 financial year surveyed (Table 5) which enabled philanthropy (Scholten, 2008). The airlines all made philanthropic contributions confirming the suspicion that financial performance preceded social performance (ibid). These profits could perhaps be classified as 'good' profits (Dowling, 2008). The proportion of spend to profits was not calculable owing to lack of comparable metrics so it is not possible to assess whether or not the airlines' contributions were 'generous' or by what standard generosity should be assessed.

\subsection{Motivations}

The programmes could not be specifically aligned with the Husted and Salazar (2006) motivation criteria. Uniquely, one programme could possibly have delivered the recommended psychological links (Devinney et al., 2006) between social and functional CSR/CSERplus programmes - the Lufthansa bereavement endowment for the families of one of their crashed aircraft - but this was not explicit. The programmes were also reconsidered using Carroll's (1979) strategic corporate criteria (reactive, accommodative, defensive and proactive). Again none were found to contribute directly to allocative or productive airline efficiency.

It would appear that airline philanthropy is applied primarily to social or environmental problems (e.g. education, arts, culture and humanitarian aid) (Table 5). Some were closer to CRM such as Lufthansa's contribution to the successful football industry for which there was no metric such as 'cost per reach' or 'sales related to sponsorship spend' (Jacobs et al., 2014). 
CRM in this instance was clearly a form of sponsorship and any strategic contribution to preventing government intervention, lowering costs or increasing sales was not obvious. It might however, have supported the altruism or egoism of the managers (Husted and Salazar, 2006). Some environmental programmes included in this analysis were beyond CSERregulated requirements and were CSR/CSERplus philanthropy such as Emirates' anti-poaching rhino orphanage or Qatar Airways' wildlife and animal welfare. Again, the strategic links were not expressed.

Local community projects featured widely (as recommended by UNCTAD, 2013; WBCSD, 1999; Kotler and Lee, 2005; Becchetti and Ciciretti, 2009; Lee et al., 2013) e.g. Singapore, ANA, Qantas, Eva Air. Programme themes ranged from children's medical, wheelchair banks, humanitarian relief through to rainforest support. All the programmes selected fulfilled the aspiration for voluntary, discretionary contributions (WBCSD, 1999; European Commission, 2002; Coles et al., 2014) which took the airlines beyond their legal requirements (McWilliams and Siegel, 2001; Kotler and Lee, 2005).

\subsection{Success measurement}

Philanthropy weaves through areas for which there are no recognised markets (McWilliams and Siegel, 2011) and measurement is often ignored as it is sometimes difficult to justify voluntary, discretionary contributions if they have to be accurately measured and fully disclosed. Few airlines disclosed the full values of their CSERplus programmes (column 3, Table 5) and often the values were hidden by metrics which external stakeholders could not monetise for comparative purposes (including "staff volunteering hours", "customer loyalty miles", "reduced price or complimentary tickets"). Consequently it was not possible to determine proportionality of contribution as a percentage of profits.

Since there were no success measures it was not possible to assess whether these contributions furthered airlines' strategic interests. Only Cathay Pacific would appear to have some measures of successful outcomes (for their "English on Air" programme for local youth).

The challenge of finding comparable metrics as requested by the SRIs was unresolved. It may be that by obscuring metrics and avoiding monetising the airlines can overstate or burnish their philanthropic actions. The target readership for the reports (government and owners ( $1^{\text {st }}$ equal), customers $\left(3^{\text {rd }}\right)$ and employees and managers $4^{\text {th }}$ equal with NGOs at $9^{\text {th }}$ (Kuo et al., 2016: 190)) does not chime with the customer service ranking for airline profitability i.e. 
employees (Yee et al., 2008) and customers $1^{\text {st }}$. Without the customers there is no economically sustainable airline therefore they should be the primary stakeholders for such reports and yet by excluding CSR/CSERplus projects from the Skytrax criteria, the link between customer and airline philanthropy is incomplete. In terms of profitability every action taken by an airline is to service customers competitively. While customers might unknowingly be targeted as report readers, what they know and value are the Skytrax criteria - not voluntary, discretionary contributions.

\subsection{Stakeholder targetting}

It was not immediately apparent which primary stakeholder groups (Clarkson, 1995) were to be influenced by these CSERplus philanthropic contributions. This leads to the conclusion that these donations were to influence a secondary group and were possibly examples of 'genteel extortion' (Ancell, 2017) in order to maintain the airlines' implicit 'licence to operate' (Sternberg, 2009), provide altruistic or egoistic benefit for the managers (Husted and Salazar, 2006) - or to assuage some of their guilt, show sympathy or fairness, confirm an ethic for duty or simply to fulfil a desire for personal recognition (Andreoni, 1988). The secondary grouping could also have included the SRI community since none of the CSR/CSERplus programmes prevented government intervention (the primary target of such reports (Kuo et al., 2016)) while any failure of CSER management activity identified by their regulated and monitored performance metrics would have alerted regulators to any discrepancies. The lack of identifiable strategic corporate purpose for CSERplus philanthropic contributions tends to indicate altruism and egoism (Husted and Salazar, 2006) possibly to placate stakeholders to retain the implicit 'licence to operate' (Sternberg, 2009) (i.e. genteel extortion). The winning stakeholders from such contributions are the NGOs which benefit from such largesse and possibly the managers (undermining the principal-agency relationship).

To the frustration of the SRIs, many of the real costs of CSR/CSERplus are incomparable and hidden including the costs of administering CSR/CSERplus programmes and the annual reworking and production of CSER management and CSR/CSERplus philanthropy reports. The information and data available supporting some of the CSR/CSERplus programmes was minimal - often no more than advertising (McWilliams and Siegel, 2001). The exception was Eva Air (2015) which attempted to monetise its CSR/CSERplus spending. Now that CSR/CSERplus is an integral part of airlines' activities, repealing it could be easily misinterpreted by those who attempt 'genteel extortion'. If voluntary, discretionary CSR/CSERplus contributions do not qualify as economically allocatively or productively efficient 
then they are by default unsustainable (Vogel, 2005; Inoue and Lee, 2011), altruistic or egoistic (Husted and Salazar, 2006) and awarded at the behest of managers using their concept of what is in the public good (Friedman, 1982). The managers' role is to grow the airlines on behalf of the owners. If customers believe there is minimal value from CSR/CSERplus philanthropic activities (especially if services and products are being reduced) then the spending might be counter-productive (Seo et al., 2015), and actually serve the airline negatively (ibid). This might explain the opaqueness of the costs - too much transparency might actually harm the airline as it could highlight waste. This could undermine any aspirational competitive advantage (Kuo et al., 2016) which might have been gained from the annual CSER management or CSR/CSERplus philanthropic reports.

Since the values of contributions were impossible to total, it was not feasible to assess whether the airlines fitted somewhere between the older environmentally damaging industries (e.g. mining) which make larger donations to charity than the newer, purportedly cleaner industries (e.g. IT) which actually give less to charity (Brammer and Millington, 2008). It was also not possible to determine the impact on the price of airline tickets since the full costs of administering these programmes was not identifiable. Few customers' voluntary, discretionary contributions to offset negative emissions were noted which implies passengers did not want to voluntarily increase their fares (i.e. their morals stopped at their pocket book (Devinney et al., 2006)).

\subsection{Transparency}

There is a balance between disclosure and secrecy. An excess of disclosure would undermine competitiveness and yet the opaqueness in these reports is not in accordance with the openness and transparency required by NMSGs, NGOs and SRIs. Transparency would benefit if the CSR/CSERplus contributions were categorised as 'philanthropy' and the full monetised costs were published. Historically, CSR campaigns have not been known to increase sales (Devinney et al., 2006) and any philanthropic gesture should show a "clear connection between social features and functional features" by providing "a psychological connection" (ibid: 36). It was challenging to find any psychological connections between the social and functional features of all of the CSR/CSERplus programmes (apart from possibly the Lufthansa bereavement project). 


\subsection{Competition}

These voluntary, discretionary contributions were innovative in that none seemed to be duplicated. In theory these donations should contribute to differentiating airlines and improve competitiveness leading to increased sales. However, it was not possible to discern who, in the primary stakeholder group, would have benefitted from the CSR/CSERplus philanthropic contributions or from reading the CSER management reports.

\section{CONCLUSION}

CSER-management is legislated, regulated best practice which makes airlines profitable. CSR/CSERplus-philanthropy is the voluntary, discretionary contribution beyond legal requirements. It is CSER management practices - not CSR/CSERplus philanthropy - which make airlines economically sustainable and enables philanthropy.

This study was a one-year snapshot of some worthy CSR/CSERplus philanthropy and any alignment to business investment was not apparent. An economically-sustainable airline is one which is productively and allocatively efficient with minimal wastes of all types. However, if philanthropy is neither transparently motivated nor measured and does not (a) prevent unfavourable government intervention (b) create product differentiation to increase sales or (c) trigger cost reductions, it is not strategic and could be considered a by-product of managerial egoism or altruism. It is therefore an expense and an increase in costs. If (under pressure from NMSGs or NGOs) the strategic justification for philanthropy is to retain the 'licence to operate', then the CSR/CSERplus contributions could be considered as 'genteel extortion'. Furthermore without justification for their philanthropy managers are breaching the principal-agency relationship and by increasing costs, could be sacrificing owners' dividends, employees' or suppliers' rewards and/or customers' products and services.

The CSR/CSERplus contributions examined in these 10 airlines did not appear to be functionally linked to increased sales (i.e. as investments) since philanthropy is not considered a criterion for membership of a customer satisfaction survey (remembering that customers' morality stops at their pocket books). Lack of transparency enabled full costs to be understated and often hidden behind non-monetised metrics. This could have been intentional especially if the contributions were made to support altruistic or egoistic managers who decide what is (in their view) best for the social good. Although the proportion of contributions disclosed 
in relation to profits appeared small, its comparison with costs reductions obtained from cutting customers' products and services would have been useful.

Primary stakeholders (critical to the airline) who benefit from airlines' CSR/CSERplus philanthropy are not identified. Recipients would appear to be secondary stakeholders - those who are not essential to the organisation and who do not transact with it. When costs are tightly controlled in order to maintain competitiveness and fund innovation for resilience, competitiveness and growth, any voluntary, discretionary contributions beyond legal requirements warrant disclosure of the selection rationale - especially if cost reductions directly affect passengers' comfort and expectations. In the absence of identifiable, measurable and strategically justifiable outcomes, CSR/CSERplus philanthropy could negatively affect competitiveness because as an expense, it only increases costs.

\section{LIMITATIONS}

It is recognised that there might have been justifiable strategies for these programmes of which report readers would be unaware.

\section{ACKNOWLEDGEMENT}

This manuscript was substantially improved by the insights and critical assessment from two anonymous reviewers.

\section{REFERENCES}

- ANA, (2016), Soaring to new heights - annual report 2016 available from https://www.ana.co.jp/group/en/investors/irdata/annual/pdf/16/16 E 00.pdf accessed on 10 April 2017

- Ancell, D. (2017) Clipped wings: corporate social and environmental responsibility in the airline industry, Routledge, London and New York

- Andreoni, J. (1988), Privately provided public goods in a large economy: the limits of altruism, Journal of Public Economics 35(1) 57-73 available from http://econweb.ucsd.edu/ jandreon/Publications/JPubE88Limits.pdf accessed 6 March 3017

- Barone, M.J., Miyazaki, A.D. \& Taylor, K.A. (2000) The influence of cause-related marketing on consumer choice: Does one good turn deserve another? Journal of the Academy of Marketing Science 28(2) pp 248-262 available from https://link.springer.com/article/10.1177/0092070300282006 accessed 5 March 2017

- Becchetti, L. and Ciciretti, R. (2009), Corporate social responsibility and stock market performance, Applied Financial Economics, 19(16) pp 1283-1293 available from 
http://www.tandfonline.com/doi/abs/10.1080/09603100802584854 accessed 9 February 2017

- Brammer, S. and Millington, A. (2008) Does it pay to be different? An analysis of the relationship between corporate social and financial performance Strategic Management Journal 29(12) pp1325-1343 available from http://onlinelibrary.wiley.com/doi/10.1002/smj.714/abstract accessed on 6 March 2017

- Braun, V. and Clarke, V. (2006), Using thematic analysis in psychology, Qualitative Research in Psychology, 3(2) pp77-101 available from https://www.tandfonline.com/doi/abs/10.1191/1478088706qp063oa accessed on 17 July 2018

- Carroll A.B. (1979) A three-dimensional conceptual model of corporate performance, Academy of Management Review 4(4) pp 497-505 available from https://www.jstor.org/stable/257850?seq=1\#page scan tab contents accessed 5 March 2017

- Carroll, A. and Shabana, K.M. (2010) The Business Case for Corporate Social Responsibility: A Review of Concepts, Research and Practice, International Journal of Management Reviews 85-105 available from http://f2.washington.edu/fm/sites/default/files/Business\%20Case\%20for\%20CSR\%20Re view\%20of\%20Concepts,\%20Research\%20and\%20Practice.pdf accessed 17 February 2017

- Cathay Pacific (2015) Sustainable development report 2015 available from http://downloads.cathaypacific.com/cx/aboutus/sd/2015/wp-

content/themes/cathay/assets/pdf/CX SDR2015 main text.pdf accessed 10 April 2017

- Clarkson, M.B.E. (1995), A stakeholder framework for analysing and evaluating corporate social performance, Academy of Management Review 20(1) 92-117 available from www.jstor.org/stable/258888?seq=1\#page scan tab contents accessed 1 January 2015

- Coles, T., Fenclova, E. and Dinan, C, (2013) Corporate social responsibility reporting among European low-fares airlines: challenges for the examination and development of sustainable mobilities, Journal of Sustainable Tourism 22(1), pp69-88 available from https://ore.exeter.ac.uk/repository/handle/10871/16436 accessed 5 March 2017

- Cowper-Smith, A. and de Grosbois, D. (2011), The adoption of corporate social responsibility practices in the airline industry, Journal of Sustainable Tourism 19(1) 59-77 available from http://www.tandfonline.com/doi/abs/10.1080/09669582.2010.498918 accessed 23 February 2017

- Devinney, T., Auger, A., Eckhardt, G. and Birtchnell, T. (2006) The other CSR, Stanford Social Innovation Review, Fall 2006: 4(3) pp30-37 available from https://papers.ssrn.com/sol3/papers.cfm?abstract id=901863 accessed 6 March 2017

- Dowling,G. R. (2008), How the tension between "good" and "bad" profits can wreak havoc with a company's reputation, Business Strategy Series, 9(1) pp24-30 available from http://dx.doi.org/10.1108/17515630810923649 accessed 17 February 2017

- Emirates (2016) Accelerating: the Emirates Group Annual Report 2015-16 available from http://content.emirates.com/downloads/ek/pdfs/report/annual report 2016.pdf accessed 10 April 2017

- Etihad (2015) CSR progress report available from http://resources.etihadairways.com/etihadairways/images/E Book/CSR Report2015 Eng lish/assets/common/downloads/CSR\%20Report\%202015\%20English.pdf accessed 10 April 2017

- European Commission (2002) Communication from the Commission concerning corporate social responsibility: a business contribution to sustainable development available from http://ec.europa.eu/europeaid/communication-commission-concerning-corporate-socialresponsibility-business-contribution en accessed 17 February 2017 
- European Commission (2016) The EU Emissions Trading Scheme (ETS) available from https://ec.europa.eu/clima/sites/clima/files/factsheet ets en.pdf accessed 10 April 2017

- EVA Air (2015), 2015 EVA AIR Corporate Social Responsibility Report available from http://www.evacsr.com/pages/en-us/ch9/download.aspx accessed 10 April 2017

- Fang, S.R., Huang, C.-Y., Huang, S. W-L., (2010) Corporate social responsibility strategies, dynamic capability and organisational performance: Cases of top Taiwan-selected benchmark enterprises, African Journal of Business Management 4(1), pp. 120-132 available from http://www.academicjournals.org/journal/AJBM/article-full-textpdf/7261EC921013 accessed 13 February 2017

- Friedman, M. (1982), Capitalism and Freedom, Chicago, IL, Chicago University Press

- Friedman, M. (2007), The social responsibility of business is to increase its profits, Corporate Ethics and Corporate Governance 173-178 available from http://link.springer.com/chapter/10.1007\%2F978-3-540-70818-6 14 accessed 29 November 2014

- Husted, B. and Salazar, J.J. (2006), Taking Friedman seriously: maximising profits and social performance, Journal of Management Studies 43(1) 75-91 available from http://onlinelibrary.wiley.com/doi/10.1111/j.1467-6486.2006.00583.x/abstract accessed 20 February 2017

- Iklhanizadeh S. and Karatepe, O.M. (2017), An examination of the consequences of corporate social responsibility in the airline industry: work engagement, career satisfaction and voice behaviour, Journal of Air Transport Management 59 8-17 available from https://www.researchgate.net/publication/309740823 An examination of the consequ ences of corporate social responsibility in the airline industry Work engagement car eer satisfaction and voice behavior accessed 2 March 2017

- Intergovernmental Panel on Climate Change (IPCC) (2013), Annex III: Glossary [Planton, S. (ed.)], in Climate Change 2013: The Physical Science Basis. Contribution of Working Group I to the Fifth Assessment Report of the Intergovernmental Panel on Climate Change, Stocker, T.F., Qin, D., Plattner, G.-K., Tignor, M., Allen, S.K., Boschung, J., Nauels, A., Xia, Y., Bex, V. and Midgley, P.M. (eds), Cambridge and New York, Cambridge University Press available from

https://www.ipcc.ch/pdf/assessmentreport/ar5/wg1/WG1AR5 SummaryVolume FINAL.pdf accessed 4 March 2017

- International Air Transport Association (IATA) (2015), 2015 IATA Global Passenger Survey available from https://www.iata.org/publications/Pages/global-passenger-survey.aspx accessed 6 March 2016

- International Air Transport Association (2016) Fact sheet: economic and social benefits of air transport available from https://www.iata.org/pressroom/facts figures/fact sheets/Documents/fact-sheeteconomic-and-social-benefits-of-air-transport.pdf accessed on 17 February 2016

- Jacobs, J., Jain, P. and Surana, K. (2014), Is sports sponsorship worth it? McKinsey \& Company available from http://www.mckinsey.com/business-functions/marketing-andsales/our-insights/is-sports-sponsorship-worth-it accessed 6 August 2014

- Joffe, H. and Yardley, L. (2004) Content and thematic analysis in Research methods for clinical and health psychology, eds Marks, D.F. and Yardley, L., London, Thousand Oaks and New Delhi, SAGE Publications

- Kinder, Lydenburg, Domini (n.d.) Corporate statement available from http://web.net/ robrien/papers/sri/players/kld.html accessed 18 February 2017

- Kotler, P. and Lee, N. (2005) Corporate Social Responsibility: Doing the Most Good for Your Company and Your Cause, Hoboken, NJ, Wiley

- Kucukusta, D., Guillet, B.D., and Chan, H.L. (2017), The effect of CSR practices on employee affective commitment in the airline industry, Journal of China Tourism Research, 12

(3-4),

pp451-469

available

from 
http://www.tandfonline.com/doi/abs/10.1080/19388160.2016.1278187 accessed 2 March 2017

- Kuo, T.C., Kremer, G.E.O., Phuong, N.T. and Hsu, C.-W. (2016) Motivations and barriers for corporate social responsibility reporting: evidence from the airline industry, Journal of Air Transport Management, $\mathbf{5 7}$ pp 184-195 available from http://www.sciencedirect.com/science/article/pii/S0969699716301028 accessed 6 March 2017

- Lee, M.-D. P. (2008) A review of the theories of corporate social responsibility: its evolutionary path and the road ahead, International Journal of Management Reviews, 10, pp. 53-73 available from https://papers.ssrn.com/sol3/papers.cfm?abstract id=1094114 accessed on 2 March 2017

- Lee, S., Seo, K. and Sharma, A. (2013), Corporate social responsibility and firm performance in the airline industry: The moderating role of oil prices, Tourism $\begin{array}{lllll}\text { Management, } & \mathbf{3 8} & \mathrm{pp20}-30 & \text { available } & \text { from }\end{array}$ http://www.sciencedirect.com/science/article/pii/S0261517713000526 accessed 11 March 2017

- Lufthansa

(2016),

Balance

available from https://www.lufthansagroup.com/fileadmin/downloads/en/LH-sustainability-report2016.pdf accessed 9 April 2017

- Lynes, J.K. and Andrachuk, M. (2008) Motivations for corporate social and environmental responsibility: a case study of Scandinavian Airlines, Journal of International Management 14 pp377-390 available from http://www.sciencedirect.com/science/article/pii/S1075425308000707 accessed on 3 March 2017

- Martinez, P. and Bosque, I. R. (2013), CSR and customer loyalty: the roles of trust, customer identification with the company and satisfaction, International Journal of Hospitality Management, 35 pp89-99 available from https://www.deepdyve.com/lp/elsevier/csr-and-customer-loyalty-the-roles-of-trustcustomer-identification-gdhxFS5Vp0 accessed on 2 March 2017

- McWilliams A. and Siegel, D. (2000) Corporate Social Responsibility and Financial Performance: Correlation or Misspecification?, Strategic Management Journal, Vol. 21, No. 5 pp. 603-609 https://www.researchgate.net/publication/229641498 Corporate social responsibility a nd financial performance Correlation or misspecification accessed 13 February 2017

- McWilliams, A. and Siegal, D. (2001) Corporate Social Responsibility: a theory of the firm perspective, Academy of Management Review 26(1) pp117-127 available from https://www.jstor.org/stable/259398?seq=1\#page scan tab contents accessed 7 March 2017

- McWilliams, A., and Siegal, D. (2011) Creating and capturing value: strategic corporate social responsibility, resource-based theory and sustainable competitive advantage Journal of Management, 37(5) pp1480-1495 available from http://journals.sagepub.com/doi/abs/10.1177/0149206310385696 accessed 22 April 2017

- Nikbin, D., Hyun, S., Iranmanesh, M. Maghsoudi, A. and Jeong, C. (2016) Airline travellers' causal attribution of service failure and its impact on trust and loyalty formation: the moderating role of corporate social responsibility, Asia Pacific Journal of Tourism Research, 21(4) 355-374 available from http://www.tandfonline.com/doi/abs/10.1080/10941665.2015.1048265?journalCode=rap t20 accessed 7 March 2017

- Plume, K. (2008) CSR-Einfuhrendes zu einem Trend [Introduction to a trend] in GATE e. V(Eds) Corporate social responsibility im tourismus (pp20-25) Berlin: GTE - Netzwerk, Tourismus, Kultur e.V. 
- Porter M.E. and Kramer, M.R. (2006), Strategy and society: the link between competitive advantage and corporate social responsibility, Harvard Business Review, 84 pp2-17 available from https://hbr.org/2006/12/strategy-and-society-the-link-betweencompetitive-advantage-and-corporate-social-responsibility accessed 16 February 2017

- Qantas (2016) A strong, sustainable future: Qantas Annual Review 2015 available from http://investor.qantas.com/FormBuilder/ Resource/ module/doLLG5ufYkCyEPjF1tpgyw/f ile/annual-reports/qantas annual review 2015.pdf accessed on 17 February 2017

- Qatar Airways (2016), Qatar Airways Group Sustainability Report 2015-16 available from http://www.qatarairways.com/iwov-resources/temp-docs/csr/sustainability-report.pdf accessed on 10 April 2017

- Scholtens, B. (2008) A note on the interaction between corporate social responsibility and financial performance, Ecological Economics 68(1-2) pp46-55 available from http://www.sciencedirect.com/science/article/pii/S0921800908000712 accessed 17 April 2017

- Schwartz, M.S. and Carroll, A. B. (2003), Corporate social responsibility - a three domain approach, Business Ethics Quarterly 13(4) 503-530 available from https://www.researchgate.net/profile/Archie Carroll/publication/261827186 Corporate S ocial Responsibility A Three-Domain Approach/links/54a17ab80cf267bdb902c00f.pdf accessed 25 February 2017

- Seo, K., Moon, J. and Lee, S. (2015) Synergy of corporate social responsibility and service quality for airlines: the moderating role of carrier type, Journal of Air Transport Management available

from http://www.sciencedirect.com/science/article/pii/S0969699715000666 accessed on 3 March 2017

- Singapore Airlines (2016) Sustainability report FY 2016-16 available from https://www.singaporeair.com/saar5/pdf/Investor-Relations/AnnualReport/sustainabilityreport1516.pdf accessed 10 April 2017

- Skytrax (2016) The world airline awards methodology (2016) available from http://www.worldairlineawards.com/Awards/awards_methodology.htmlhttp://www.world airlineawards.com/Awards/awards methodology.html accessed 9 April 2017

- Sternberg, E. (2009), Corporate social responsibility and corporate governance, The Institute of Economic Affairs, Blackwell, Oxford available from https://papers.ssrn.com/sol3/papers2.cfm?abstract id=1512870 accessed 17 February 2017

- Turkish Airlines (2015), Sustainability report 2015 available from http://investor.turkishairlines.com/documents/ThyInvestorRelations/download/icerikler/T HY 2015 Sustainability Report WEB.pdf accessed 10 April 2017

- United Nations Conference on Trade and Development (UNCTAD) (2013) Corporate social responsibility, available from http://unctad.org/en/Pages/DIAE/Corporate-SocialResponsibility.aspx accessed 12 April 2017

- United Nations Regional Information Centre (UNRIC) (2015) Questions to Christiana Figueres on COP21 available from https://europa.eu/eyd2015/en/unric/posts/questionscristina-figures-cop21 accessed 17 February 2017

- United Nations Sustainable Development (UNSD) (1992) United Nations Conference on Environment \& Development available from https://sustainabledevelopment.un.org/content/documents/Agenda21.pdf accessed 26 February 2017

- Vogel, D.J. (2005), Is there a market for virtue? The business case for corporate social responsibility, California Management Review 47(4) 19-45 available from http://cmr.ucpress.edu/content/47/4/19 accessed 22 April 2017 
- Wittman, M. (2014) Are low-cost carrier passengers less likely to complain about service quality? Journal of Air Transport Management 35 pp 64-71 available from https://www.researchgate.net/publication/259519728 Are lowcost carrier passengers less likely to complain about service quality accessed 6 March 2017

- World Business Council for Sustainable Development (WBCSD) (1999) Corporate social responsibility: meeting changing expectations available from http://old.wbcsd.org/pages/edocument/edocumentdetails.aspx?id=82\&nosearchcontextk ey=true accessed 17 February 2017

- Yee, R.W.Y., Yeung, A.C.L. and Cheng, T.C.E. (2008), The impact of employee satisfaction on quality and profitability in high-contact service industries, Journal of Operations $\begin{array}{lllll}\text { Management } & 26 & 651-668 & \text { available }\end{array}$ http://www.sciencedirect.com/science/article/pii/S0272696308000028 accessed 1 January 2015. 